\title{
PENGARUH KOMPETENSI TERHADAP KINERJA PEGAWAI FAKULTAS EKONOMI UNIVERSITAS PGRI PALEMBANG
}

\author{
Tri Darmawati *)
}

\begin{abstract}
ABSTRAK
Penelitian ini bertujuan untuk mengetahui Pengaruh Kompetensi Terhadap Kinerja Pegawai Pada Fakultas Ekonomi Universitas PGRI Palembang Populasi dalam penelitian ini adalah seluruh pegawai yang bekerja pada Fakultas Ekonomi Universitas PGRI Palembang yang berjumlah 35 pegawai, sedangkan sampel dalam penelitian ini sebanyak 35 responden. Teknik pengambilan sampel dalam penelitian ini menggunakan teknik probability sampling dengan cara simple random sampling. Hasil penelitian menunjukan bahwa ada Pengaruh Kompetensi Terhadap Kinerja Pegawai Pada Fakultas Ekonomi Universitas PGRI Palembang, hal ini sesuai dengan uji hipotesis memperlihatkan nilai t sebesar 2,532 dengan nilai signifikansi sebesar 0,169 sehingga tolak hipotesis nol dan terima hipotesis alternatif yaitu ada pengaruh kompetensi terhadap kinerja pegawai Fakultas Ekonomi Universitas PGRI Palembang.
\end{abstract}

Kata Kunci : Kompetensi , Kinerja Pegawai

\section{PENDAHULUAN}

Seiring dengan semakin
meningkatnya kesadaran dalam
memandang manusia sebagai aset bagi perusahaan, maka timbul suatu kajian baru dalam perkembangan manajemen, yaitu manajemen sumber daya manusia. Sumber daya manusia dapat tetap bertahan karena mereka memiliki kompetensi manajerial, yaitu kemampuan untuk merumuskan visi dan strategi perusahaan serta kemampuan untuk memproleh dan mengarahkan sumber daya lain dalam rangka mewujudkan visi dan menerapkan strategi perusahaan.

Dalam rangka operasional, kompetensi merupakan salah satu faktor dari sumber daya manusia di Fakultas Ekonomi Universitas PGRI Palembang yang harus diperhatikan sehingga mampu mengefektifkan dan mengefisienkan proses kinerja pegawai,

Kompetensi adalah suatu kemampuan yang dilandasi oleh keterampilan dan pengetahuan yang didukung oleh sikap kerja serta penerapannya dalam melaksanakan tugas yang telah ditetapkan. Keberadaan perguruan tinggi sebagai salah satu institusi pendidikan dalam kehidupan di masyarakat sangat penting dan dibutuhkan. Persaingan antar perguruan tinggi juga terjadi dengan berdirinya perguruan tinggi swasta lainnya yang berkembang dengan pesat dengan kualitas dan pelayanan yang berbeda. Oleh karenanya perlu adanya peningkatan sumber daya manusia perguruan tinggi sehingga dapat mempengaruhi kualitas dan kelangsungan mutu perguruan tinggi.

Beberapa faktor yang dapat mempengaruhi kelancaran dari aktivitas perguruan tinggi adalah faktor kompetensi yang dimiliki sumber daya manusia, sarana dan prasarana serta pelayanan dan kinerja pegawai. Dari ke-empat faktor ini, dapat diketahui bahwa faktor utama yang mempengaruhi kelangsungan hidup aktivitas perguruan tinggi adalah faktor kinerja pegawainya.

Pada suatu perguruan tinggi sumber daya manusia merupakan salah satu faktor yang paling penting dalam proses pencapaian tujuan yang baik diperguruan tinggi. Sumberdaya yang berkualitas sangat berperan dalam mengoperasikan teknologi 
canggih dan menjalankan strategi bisnis secara optimal dalam menghadapi persaingan bisnis yang semakin tajam. Untuk memenuhi sumber daya manusia yang berkualitas, sumber daya manusia harus menjadikan manusia-manusia pembelajar seperti pribadi-pribadi yang mau belajar dan bekerja keras dengan penuh semangat sehingga potensi insaninya berkembang maksimal.

\section{Perumusan Masalah}

Agar tidak menyimpang dari permasalahan yang ada, maka yang menjadi rumusan masalah dalam penelitian ini adalah "Adakah Pengaruh Kompetensi Terhadap Kinerja Pegawai pada Fakultas Ekonomi Universitas PGRI Palembang?".

\section{Tujuan Penelitian}

Berdasarkan masalah yang telah dikemukaan diatas, maka yang menjadi tujuan dalam penelitian ini adalah untuk mengetahui pengaruh kompetensi terhadap kinerja pegawai pada Fakultas Ekonomi Universitas PGRI Palembang.

\section{Kajian Pustaka}

Kompetensi adalah suatu kemampuan yang dilandasi oleh keterampilan dan pengetahuan yang didukung oleh sikap kerja serta penerapannya dalam melaksanakan tugas yang telah ditetapkan.

Untuk membahas pengertian kompetensi akan penulis kemukakan menurut pendapat beberapa ahli sebagai berikut :
1. Menurut Spencer (2005:203) kompetensi adalah suatu yang mendasari karakteristik dari individu yang dihubungkan dengan hasil yang diperoleh dalam suatu pekerjaan. Karakteristik dasar

kompetensi berarti kemampuan adalah sesuatu yang kronis dan dalam bagian dari kepribadian seseorang dan dapat diramalkan perilaku didalam suatu tugas pekerjaan.

2. Menurut Boulter, Dalziel, Hill (2005:203) Kompetensi adalah suatu karakteristik dasar dari seseorang yang memungkinkannya memberikan kinerja unggul dalam pekerjaan, peran, atau situasi tertentu.

3. Menurut Mulyasa (2005:203) Kompetensi merupakan perpaduan dari pengetahuan, ketrampilan, nilai, dan sikap yang direfleksikan dalam kebiasaan berpikir dan bertindak.

4. Menurut McAshan (2005:203) Kompetensi adalah pengetahuan, ketrampilan, dan kemampuan yang dikuasai oleh seseorang yang telah menjadi bagian dari dirinya.

5. Menurut Finch dan Crunkilton (2005:204) Mengartikan kompetensi sebagai penguasaan terhadap suatu tugas, ketrampilan, sikap, dan apresiasi yang diperlukan untuk menunjang keberhasilan.

Dari pengertian diatas dapat disimpulkan bahwa kompetensi adalah suatu kemampuan yang dilandasi oleh keterampilan dan pengetahuan yang didukung oleh sikap kerja serta penerapannya dalam melaksanakan tugas yang telah ditetapkan.

Menurut Gordon (2005:204) menjelaskan ada beberapa aspek yang terkandung dalam konsep kompetensi sebagai berikut:

a. Pengetahuan (knowledge),yaitu kesadaran dalam bidang ekonomi kognitif. Misalnya, seorang pegawai mengetahui cara melakukan identifikasi belajar, dan bagaimana melakukan pembelajaran yang baik sesuai 
dengan kebutuhan yang ada di perusahaan.

b. Pemahaman (understanding), yaitu kedalaman kognitif, dan efektif yang dimiliki oleh individu. Misalnya, seorang pegawai dalam melaksanakan pembelajaran harus mempunyai pemahaman yang baik tentang karakteristik dan kondisi secara efektif dan efisien.

c. Kemampuan (skill), adalah sesuatu yang dimiliki oleh individu untuk melaksanakan tugas atau pekerjaan yang dibebankan kepadanya. Misalkan, kemampuan pegawai dalam memilih metode kerja yang dianggap lebih efektif dan efisien.

d. Nilai (value), adalah suatu standar perilaku yang telah diyakinin dan secara psikologis yang telah menyatu dalam diri seseorang. Misalnya, standar perilaku para pegawai dalam melaksanakan tugas ( kejujuran, keterbukaan, demokratis, dan lain - lain).

e. Sikap (attitude), adalah perasaan (senang tidak senang, suka-tidak suka) atau reaksi terhadap suatu perasaan yang datang dari luar. Misalnya, reaksi terhadap krisis ekonomi, perasaan terhadap kenaikan gaji, dan sebagainya.

f. Minat (interest), adalah kecenderungan seseorang untuk melakukan suatu perbuatan. Misalnya, melakukan suatu aktivitas kerja.

Pentingnya kinerja karena kinerja adalah merupakan hasil pekerjaan yang mempunyai hubungan kuat dengan tujuan strategis organisasi, kepuasan konsumen, dan memberikan kontribusi pada ekonomi. Kinerja berasal dari pengertian performance. Ada pula yang memberikan pengertian performance sebagai hasil kerja atau pertasi kerja. Namun, sebenarnya kinerja mempunyai makna yang lebih luas, bukan hanya hasil kerja, tetapi termasuk bagaimana proses pekerjaan berlangsung.

Menurut Armstrong (2007:10) kinerja adalah pendekatan strategis dan terpadu untuk menyampaikan sukses berkelanjutan pada organisasi dengan memperbaiki kinerja pegawai bekerja didalamnya. Menurut Schwart (2007:9) kinerja sebagai gaya manajemen yang dasarnya adalah komunikasi terbuka antara manajer dan pegawai yang menyangkut penetapan tujuan, memberikan umpan balik baik dari manajer kepada pegawai maupun seebaliknya pegawai kepada manajer. Menurut Costello (2007:11) kinerja merupakan dasar dan kekuatan pendorong yang berada dibelakang semua keputusan organisasi, usaha kerja, dan alokasi sumber daya. Indikator-indikator kinerja adalah :

1. Kualitas kerja adalah Kegunaan (useability) adalah adanya kemudahan untuk mencari informasi yang disajikan ,yang ditinjau dari kemudahan mengakses informasi dari berbagai jenis komputer secara cepat.

2. Efesiensi kerja adalah merupakan suatu prinsip dasar untuk melakukan setiap kegiatan suatu organisasi dengan tujuan untuk dapat memperoleh hasil yang dikehendaki dengan usaha yang seminimal mungkin dengan standar yang ada,usaha yang seminimal mungkin tersebut dikaitkan dalam hubungannya dengan pemakaian tenaga jasmani, pikiran, waktu, ruang, benda, dan uang.

3. Pelayanan adalah merupakan proses pembelajaran jangka panjang dimana manajer membantu orang lain agar menjadi lebih baik dan memperbaiki ketrampilan,dan kemampuan dalam membantu 
4. Tanggung jawab adalah menerima tanggung jawab atas apa yang mereka kerjakan dan tidak kerjakan untuk mencapai tujuan mereka belajar tentang apa yang perlu mereka perbaiki.

5. Kerja Sama adalah ketersediaan untuk member dan menerima kontribusi kepada mitra kerja dalam mencapai sasaran dan target perusahaan.

6. Fasilitas kerja adalah merupakan salah satu alat yang digunakan oleh pegawai untuk memudahkan dalam penyelesaian kerja sehari - hari.

Berdasarkan kajian pustaka diatas maka hipotesis penelitian ini adalah:

Ho: Tidak ada pengaruh antara kompetensi terhadap kinerja pegawai pada Fakultas Ekonomi Palembang.

$\mathrm{Ha}$ : Ada pengaruh antara kompetensi terhadap kinerja pegawai pada Fakultas Ekonomi Palembang.

\section{Metode Penelitian}

Variable penelitian yang digunakan dalam penelitian ini adalah:
a. variabel bebas (variabel independen), pada penelitian ini ialah kompetensi $(\mathrm{X})$
b. variabel terikat (variabel dependen), dalam penelitian ini adalah: kinerja $(Y)$

\section{Tabel 1}

\section{Definisi Operasional Variabel}

\begin{tabular}{|c|c|c|}
\hline No & Variabel & Definisi Variabel \\
\hline 1 & Kompetensi & $\begin{array}{l}\text { Kompetensi adalah } \\
\text { suatu kemampuan yang } \\
\text { dilandasi oleh } \\
\text { keterampilan dan } \\
\text { pengetahuan yang } \\
\text { didukung oleh sikap } \\
\text { kerja serta } \\
\text { penerapannya dalam } \\
\text { melaksanakan tugas } \\
\text { vana telah ditetapkan }\end{array}$ \\
\hline
\end{tabular}

\begin{tabular}{|c|l|l|}
\hline 2 & $\begin{array}{l}\text { Kinerja } \\
\text { pegawai }\end{array}$ & $\begin{array}{l}\text { Kinerja pegawai adalah } \\
\text { merupakan hasil } \\
\text { pekerjaan yang } \\
\text { mempunyai hubungan } \\
\end{array}$ \\
& $\begin{array}{l}\text { kuat dengan tujuan } \\
\text { strategis organisasi, } \\
\text { kepuasan konsumen, } \\
\text { dan memberikan } \\
\text { kontribusi pada ekonomi }\end{array}$ \\
& &
\end{tabular}

Menurut Sugiyono (2010:115) menyatakan bahwa populasi adalah wilayah general yang terdiri atas obyek atau subyek yang mempunyai kualitas dan karakteristik tertentu yang ditetapkan oleh peneliti untuk dipelajari kemudian ditarik kesimpulannya. Populasi dalam penelitian ini adalah 35 pegawai. Menurut Sugiyono (2010:116) menyatakan sampel adalah bagian dari jumlah dan perilaku yang dimiliki populasi tersebut. Teknik pengambilan sampel dalam penelitian ini menggunakan teknik probability sampling dengan cara simple random sampling. Sehingga sampel yang digunakan dalam penelitian ini adalah sebanyak 35 pegawai. Data yang digunakan dalam penelitian ini adalah:

a. Data primer

Data primer adalah data yang dikumpulkan dan diolah sendiri oleh penulis yang menggunakannya. Seperti data hasil kuisioner yang didapat dari responden.

b. Data sekunder

Data sekunder adalah data yang digunakan oleh penulis yang merupakan data yang telah diolah. Seperti data jumlah pegawai fakultas ekonomi universitas PGRI Palembang.

Dalam

penelitian ini menggunakan model pengukuran Skala Likert dengan 5 kemungkinan persetujuan oleh responden terhadap pernyataan atau pertanyaan pada item kuesioner. Item kuesioner telah diatur mengikuti kebutuhan data untuk diuji 
hipotesis dan analisis dengan tujuan penelitian. Tabel 2 menyajikan skala pengukuran yang digunakan dan skor yang diberikan dalam penelitian ini.

Tabel 2

Skala Pengukuran

\begin{tabular}{|c|c|}
\hline Jawaban & Nilai \\
\hline Sangat Setuju & 5 \\
\hline Setuju & 4 \\
\hline Netral & 3 \\
\hline Tidak Setuju & 2 \\
\hline Sangat Tidak Setuju & 1 \\
\hline
\end{tabular}

Instrumen yang dipakai dalam penelitian ini diuji dengan uji validitas dan uji realibilitas. Uji validitas merupakan suatu alat yang digunakan untuk mengukur ketepatan, kecermatan, suatu alat ukur dalam melakukan fungsi ukurnya. Suatu tes atau instrumen pengukuran dapat dikatakan mempunyai validitas tinggi apabila alat tersebut dapat mengukur atau memberikan hasil ukur yang sesuai dengan apa yang hendak diukur.

Menurut Sugiyono (2010) dalam pengujian validitas untuk mencari harga korelasi dengan menggunakan rumus teknik korelasi product moment, sebagai berikut:

$$
r_{x y}=\frac{n \sum X Y-\sum X \cdot \sum Y}{\sqrt{n \sum x^{2}-\left(\sum x\right)^{2}\left\{n \sum Y^{2}-\left(\sum Y\right)^{2}\right\}}}
$$

Dimana :

rxy: koefisien korelasi validitas

$\mathrm{x}$ : kompetensi

$Y$ : kinerja pegawai

$\mathrm{n}$ : banyak data

Uji reabilitas adalah instrumen yang bila digunakan beberapa kali untuk mengukur objek yang sama, maka menghasilkan data yang sama. Pengujian reabilitas instrument dapat dilakukan dengan teknik belah dua dari
Spearman Brown (split half) dengan rumus sebagai berikut :

$\mathrm{Ri}=\frac{2 r b}{1+r b}$

Dimana :

$\begin{aligned} \mathrm{ri}= & \text { reabilitas internal seluruh } \\ \text { instrument } & \\ \mathrm{rb}= & \begin{array}{l}\text { korelasi product moment antara } \\ \text { belahan pertama dan kedua }\end{array}\end{aligned}$

Teknik analisis data yang penulis gunakan yakni teknik analisis data deskriptif kuantitatif, yaitu suatu metode analisis yang menggunakan menggambarkan hasil penelitian berdasarkan perhitungan angka-angka untuk pengambilan keputusan. penulis menggunakan analisis regresi linier sederhana untuk menghitung seberapa besar pengaruh antar variabel. Adapun rumus regresi linier sederhana adalah sebagai berikut :

$\begin{aligned} \boldsymbol{Y} & =\boldsymbol{\alpha}-\boldsymbol{b} \boldsymbol{X} \\ \mathrm{b} & =\frac{\sum \boldsymbol{x y}-\boldsymbol{n} \overline{(\bar{x})(\overline{\boldsymbol{y}}}}{\sum \boldsymbol{x}^{2} \boldsymbol{\overline { x }} \overline{\bar{x})^{2}}} \\ \alpha & =\bar{Y}-b \bar{x}\end{aligned}$

Keterangan :

$\mathrm{Y}=$ kinerja pegawai

$\mathrm{a}=$ bilangan konstan

$\mathrm{b}=$ koefisien regresi

$\mathrm{X}=$ kompetensi

Koefisien korelasi merupakan indeks atau bilangan yang digunakan untuk mengukur keeratan hubungan antar variabel.

Dengan rumus sebagai berikut :

$r=\frac{n \sum X Y-\sum X \sum Y}{\sqrt{\left\{n \sum X^{2}\right\}}\left\{n \sum Y^{2}\left(\sum Y^{2}\right.\right.}$

Keterangan :

$r=$ koefisien korelasi yang di cari

$\mathrm{X}=$ kompetensi

$\mathrm{Y}=$ kinerja pegawai

$\mathrm{n}=$ banyak data 
Tabel 3

Interpretasi Koefisien Korelasi

\begin{tabular}{|c|c|}
\hline Interval Koefisien & $\begin{array}{c}\text { Tingkat } \\
\text { Hubungan }\end{array}$ \\
\hline $0,00-0,19$ & Sangat Rendah \\
$0,20-0,39$ & Rendah \\
$0,40-0,59$ & Sedang \\
$0,60-0,79$ & Kuat \\
$0,80-1,00$ & Sangat Kuat \\
\hline
\end{tabular}

Penguji koefisien determinasi $\left(R^{2}\right) \quad$ bertujuan untuk mengetahui bagaimana kemampuan variabel bebas menjelaskan variabel terikat. Rumus yang digunakan sebagai berikut :

$\mathrm{KP}=\left(\mathrm{r}^{2}\right) \times 100 \%$

Dimana :

$\mathrm{KP}=$ Nilai Koefisien Determinasi

$r=$ nilai Koefisien Korelasi

Selanjutnya diukur thitung yang digunakan untuk mengetahui koefisien thitung dengan rumus :

$\mathrm{t}=\frac{r \sqrt{n-2}}{\sqrt{I-r^{2}}}$

Keterangan :

$\mathrm{t}=\mathrm{t}$ hitung yang selanjutnya dibandingkan dengan $t$ tabel

$r=$ koefisien korelasi

$\mathrm{n}=$ jumlah sampel

Untuk membantu pengolahan data maka penulis menggunakan software statistik SPSS Versi 15.0.

\section{Hasil Penelitian}

Uji validitas dalam penelitian ini dengan menggunakan teknik koefisien korelasi Pearson's Product Moment atau $r$ hitung dan menggunakan perbandingan dengan nilai kritis atau $r$ tabel. $r$ tabel sebesar 0,482. Perhitungan korelasi atau $r$ hitung dengan menggunakan antara skor butir dan total skor dari seluruh butir variabel.

Kuesioner untuk variabel kompetensi pegawai sebanyak 12 butir pernyataan. Rekapitulasi hasil uji validitas dapat dilihat pada tabel berikut ini :

\section{Tabel 4}

Hasil Uji Validitas Variabel Kompetensi Pegawai

\begin{tabular}{|c|c|c|c|}
\hline Butir & $\begin{array}{c}\mathbf{r} \\
\text { hitung }\end{array}$ & $\mathbf{r}$ tabel & Kesimpulan \\
\hline $\mathbf{1}$ & 0,641 & 0,482 & Valid \\
\hline $\mathbf{2}$ & 0,593 & 0,482 & Valid \\
\hline $\mathbf{3}$ & 0,541 & 0,482 & Valid \\
\hline $\mathbf{4}$ & 0,618 & 0,482 & Valid \\
\hline $\mathbf{5}$ & 0,554 & 0,482 & Valid \\
\hline $\mathbf{6}$ & 0,660 & 0,482 & Valid \\
\hline $\mathbf{7}$ & 0,700 & 0,482 & Valid \\
\hline $\mathbf{8}$ & 0,665 & 0,482 & Valid \\
\hline $\mathbf{9}$ & 0,614 & 0,482 & Valid \\
\hline $\mathbf{1 0}$ & 0,693 & 0,482 & Valid \\
\hline $\mathbf{1 1}$ & 0,554 & 0,482 & Valid \\
\hline $\mathbf{1 2}$ & 0,530 & 0,482 & Valid \\
\hline
\end{tabular}

Sumber : data diolah peneliti

Dari tabel diatas menunjukkan bahwa koefisien korelasi atau $r$ hitung antara skor butir dan total skor dari seluruh variabel kompetensi pegawai diperoleh data lebih besar dari $r$ tabel. Hal ini berarti seluruh butir pernyataan pada variabel kompetensi pegawai adalah valid atau dapat dipercaya kebenarannya, sehingga kuesioner ini dapat digunakan dalam penelitian ini sebagai alat untuk mengumpulkan data.

Kuesioner untuk variabel kinerja pegawai sebanyak 12 butir pernyataan. Rekapitulasi dapat dilihat pada tabel berikut ini : 
Tabel 5

Hasil Uji Validitas Variabel Kinerja Pegawai

\begin{tabular}{|c|c|c|c|}
\hline Butir & $\begin{array}{c}\mathbf{r} \\
\text { hitung }\end{array}$ & $\begin{array}{c}\mathbf{r} \\
\text { tabel }\end{array}$ & Kesimpulan \\
\hline $\mathbf{1}$ & 0,639 & 0,482 & Valid \\
\hline $\mathbf{2}$ & 0,600 & 0,482 & Valid \\
\hline $\mathbf{3}$ & 0,628 & 0,482 & Valid \\
\hline $\mathbf{4}$ & 0,678 & 0,482 & Valid \\
\hline $\mathbf{5}$ & 0,785 & 0,482 & Valid \\
\hline $\mathbf{6}$ & 0,883 & 0,482 & Valid \\
\hline $\mathbf{7}$ & 0,547 & 0,482 & Valid \\
\hline $\mathbf{8}$ & 0,617 & 0,482 & Valid \\
\hline $\mathbf{9}$ & 0,530 & 0,482 & Valid \\
\hline $\mathbf{1 0}$ & 0,500 & 0,482 & Valid \\
\hline $\mathbf{1 1}$ & 0,578 & 0,482 & Valid \\
\hline $\mathbf{1 2}$ & 0,574 & 0,482 & Valid \\
\hline
\end{tabular}

Sumber : data diolah
Dari tabel diatas menunjukkan bahwa koefisien korelasi atau $r$ hitung antara skor butir dan total skor dari seluruh variabel kinerja pegawai diperoleh data lebih besar dari $r$ tabel. Hal ini berarti seluruh butir pernyataan pada variabel kinerja adalah valid atau dapat dipercaya kebenarannya, sehingga kuesioner ini dapat digunakan dalam penelitian ini sebagai alat untuk mengumpulkan data

Dalam penelitian ini uji reliabilitas menggunakan Cronbach's Alpha, dan nilai dari Cronbach's Alpha dibandingkan dengan nilai penerimaan reliabilitas butir skor sebesar 0,60. Berikut tabel yang menyajikan hasil uji reliabilitas, dapat dilihat pada tabel berikut ini:

Tabel 6

Hasil Uji Reliabilitas

\begin{tabular}{|c|l|c|c|}
\hline No & \multicolumn{1}{|c|}{ Variabel } & Cronbach's Alpha & Kesimpulan \\
\hline 1 & Kompetensi & 0,815 & Reliabel \\
\hline 2 & Kinerja Pegawai & 0,743 & Reliabel \\
\hline
\end{tabular}

Sumber : data diolah

Hasil uji reliabilitas diatas menunjukkan bahwa seluruh variabel kompetensi maupun kinerja pegawai mempunyai nilai lebih besar dari 0,60 sehingga dapat disimpulkan bahwa seluruh butir pernyataan dari kuesioner baik variabel kompetensi maupun kinerja pegawai adalah reliabel, berarti seluruh kuesioner yang digunakan dalam penelitian ini dapat diandalkan dan digunakan dalam penelitian ini.

Tabel berikut menyajikan hasil perhitungan korelasi dengan variabel $X$ kompetensi dan variabel $Y$ kinerja pegawai pada Fakultas Ekonomi Universitas PGRI Palembang.

Tabel 7

Koefisien Korelasi dan Koefisien Determinasi Model Summary

\begin{tabular}{|r|r|r|r|r|}
\hline Model & R & R Square & $\begin{array}{c}\text { Adjusted R } \\
\text { Square }\end{array}$ & $\begin{array}{c}\text { Std. Error of } \\
\text { the Estimate }\end{array}$ \\
\hline 1 & $.294^{\mathrm{a}}$ & .086 & .017 & 6.34926 \\
\hline
\end{tabular}

Sumber : data diolah

Berdasarkan tabel diatas dapat diketahui koefisien korelasi sebesar 0,294 . Hal ini berarti hubungan kompetensi pegawai dan kinerja pegawai adalah rendah. Selanjutnya koefisien determinasi digunakan agar mengetahui keeratan hubungan antara variabel bebas dan variabel terikat.

Berdasarkan tabel diatas dapat diketahui nilai $r$ square sebesar 0,086 , 
hal ini berarti bahwa kontribusi kompetensi terhadap kinerja pegawai sebesar $8,6 \%$ sedangkan sisanya $91,4 \%$ dipengaruhi oleh variabel lain yang tidak diteliti dalam penelitian ini. Analisis regresi linier sederhana digunakan dalam penelitian ini untuk mengetahui bagaimana pengaruh variabel bebas terhadap variabel terikat. Berikut ini tabel yang menyajikan hasil perhitungan menggunakan SPSS.

Tabel 8

Analisis Regresi Linier Sederhana Coefficients ${ }^{a}$

\begin{tabular}{|c|c|c|c|c|c|c|}
\hline \multirow{2}{*}{\multicolumn{2}{|c|}{ Model }} & \multicolumn{2}{|c|}{$\begin{array}{l}\text { Unstandardized } \\
\text { Coefficients }\end{array}$} & \multirow{2}{*}{\begin{tabular}{|c|}
$\begin{array}{c}\text { Standardized } \\
\text { Coefficients }\end{array}$ \\
Beta \\
\end{tabular}} & \multirow[b]{2}{*}{$\mathrm{T}$} & \multirow[b]{2}{*}{ Sig. } \\
\hline & & $B$ & Std. Error & & & \\
\hline \multirow[t]{2}{*}{1} & (Constant) & 35.630 & 12.185 & & 2.012 & .049 \\
\hline & Kompetensi & .142 & .256 & .183 & 2.532 & .169 \\
\hline
\end{tabular}

Sumber : data diolah

Berdasarkan tabel diatas dapat diketahui persamaan regresi dengan variabel bebas kompetensi pegawai pada Fakultas Ekonomi Universitas PGRI Palembang adalah $Y=35,630+$ $0,142 X$. Hal ini berarti koefisien regresi a sebesar 35,630 satuan menunjukan bahwa jika Fakultas Ekonomi Universitas PGRI tidak meningkatkan kompetensi pegawai maka kinerja yang dimiliki pegawai sebesar 35,630 satuan. Koefisien regresi b sebesar 0,142 satuan, hal ini menunjukkan bahwa jika terjadi perubahan kompetensi yang dimiliki pegawai berubah satu satuan maka menyebabkan perubahan kinerja pegawai sebesar 0,142 satuan secara searah.

Pengujian hipotesis dengan menggunakan uji $\mathrm{t}$ bertujuan untuk mengetahui apakah variabel independen atau kompetensi berpengaruh signifikan terhadap variabel dependen atau kinerja pegawai di Fakultas Ekonomi Universitas PGRI Palembang. Ketentuannya adalah hipotesis nol ditolak apabila thitung > ttabel dan hipotesis alternatif diterima pada $\alpha$ sebesar 0,05.
Berdasarkan tabel diatas diketahui bahwa uji hipotesis memperoleh nilai thitung 2,532 dengan nilai signifikansinya sebesar 0,169 dengan menggunakan a sebesar 0,05.

\section{Pembahasan}

Hasil analisis koefisien korelasi sebesar 0,294 berarti hubungan kompetensi pegawai dan kinerja pegawai adalah rendah. Hal ini berarti jika kompetensi pegawai diperbanyak dan ditingkatkan maka akan meningkatkan kinerja pegawai. Sebaliknya, jika kompetensi diperkecil dan menurun maka akan menurunkan kinerja pegawai.

Hasil koefisien determinasi sebesar 0,086, hal ini berarti bahwa kontribusi kompetensi terhadap kinerja pegawai sebesar $8,6 \%$ sedangkan sisanya $91,4 \%$ dipengaruhi oleh variabel lain yang tidak diteliti dalam penelitian ini. Koefisien determinasi tersebut juga memberikan arti bahwa variabel kompetensi sebagai variabel bebas dapat menjelaskan kinerja pegawai sebagai variabel terikat sebesar $8,6 \%$

Hasil regresi linier sederhana menunjukan persamaan regresi $Y=$ 
$35,630+0,142 X$. Hal ini berarti koefisien regresi a sebesar 35,630 satuan menunjukan bahwa jika Fakultas Ekonomi tidak meningkatkan kompetensi pegawai maka kinerja yang dimiliki pegawai sebesar 35,630 satuan. Koefisien regresi b sebesar 0,142 satuan, hal ini menunjukkan bahwa jika terjadi perubahan kompetensi yang dimiliki pegawai berubah satu satuan maka menyebabkan perubahan kinerja pegawai sebesar 0,142 satuan secara searah. Hal ini berarti jika kompetensi ditingkatkan maka kinerja pegawai akan meningkat, sebaliknya jika kompetensi menurun maka kinerja pegawai akan menurun, dengan demikian peningkatan kompetensi akan membantu meningkatkan kinerja pegawai pada Fakultas Ekonomi . Hasil analisis pengujian hipotesis dengan menggunakan uji t, menunjukan nilai $t$ sebesar 2,532 dengan nilai signifikansinya sebesar 0,169 dengan menggunakan $\alpha$ sebesar 0,05. Dengan nilai signifikan diatas 0,169 berarti hipotesis nol ditolak dan hipotesis alternative diterima. Hal ini berarti hasil pengujian hipotesis memberikan kesimpulan bahwa terdapat pengaruh kompetensi terhadap kinerja pegawai pada Fakultas Ekonomi Universitas PGRI Palembang, yang diperkuat oleh hasil persamaan regresi linier sederhana dengan koefisien regresi $b=0,142$ dimana koefisien regresi tersebut menunjukan adanya pengaruh positif perubahan variabel kompetensi terhadap kinerja pegawai.

\section{KESIMPULAN DAN SARAN} adalah:

Kesimpulan dari penelitian ini

1. Diperoleh koefisien korelasi sebesar 0,294 hal ini menunjukkan hubungan yang rendah antara kompetensi dengan kinerja pegawai pada Fakultas Ekonomi Universitas PGRI Palembang.

2. Diperoleh koefisien determinasi sebesar 8,6\% menunjukkan bahwa kontribusi kompetensi terhadap kinerja pegawai pada Fakultas Ekonomi Universitas PGRI palembang sebesar $8,6 \%$ sedangkan sisanya $91,4 \%$ diperoleh dari variabel-variabel lain yang tidak diteliti dalam penelitian ini.

3. Diperoleh persamaan regresi $Y=$ $35,630+0,142 X$, konstanta a sebesar 35,630 berarti jika Fakultas Ekonomi tidak meningkatkan kompetensi pegawai maka kinerja yang dimiliki pegawai sebesar 35,630 satuan, sedangkan koefisien regresi b sebesar 0,142 satuan, berarti jika terjadi perubahan kompetensi yang dimiliki pegawai berubah satu satuan maka menyebabkan perubahan kinerja pegawai sebesar 0,142 satuan secara searah.

Saran dari penelitian adalah:

1. Kompetensi sebaiknya dapat ditingkatkan terus karena akan dapat meningkatkan kinerja pegawai.

2. Untuk peneliti selanjutnya, diharapkan agar menambah variabel-variabel lain yang dapat dijadikan dalam penelitian lanjutan. Hal ini dikarenakan masih adanya variabel-variabel yang belum diteliti oleh penulis yang masih berhubungan dengan kinerja dan diduga memiliki pengaruh terhadap kinerja.

\section{DAFTAR PUSTAKA}

Armstrong, $\quad 2005$. Performance Management (alih bahasa: Tony Setiawan). Yogyakarta: Tugu 
Kirkpatrick, Donal L. 2006. Improving Employee Performace. New York: Amacom.

Mahsun, Mohammad, 2006, Pengukuran kinerja Sektor Publik, BPFE- Yogyakarta : Yogyakarta

Rivai, Veithzal. 2005. Manajemen Sumber Daya manusia untuk perusahaan. Jakarta: Raja Grafindo Persada

Sofian ,2013. Statistic parametric untuk penelitian kualitatif. Jakarta : bumi aksara

Sugiyono, 2008 Metode Penelitian Adminitrasi, Alfabeta, Bandung.

Sofian ,2013. Statistic parametric untuk penelitian kualitatif. Jakarta : bumi aksara
_ 2010. Memahami Penelitian kualitatif, Alfabeta, Bandung. 2012. Memahami Penelitian kualitatif, Alfabeta, Bandung.

Sutrisno,2009. Manajemen sumber daya manusia cetakan pertama, kencana , jakarta

Wibowo, 2007, Manajemen kinerja, edisi 3. PT, Raja Grafindo Persada : Jakarta. 